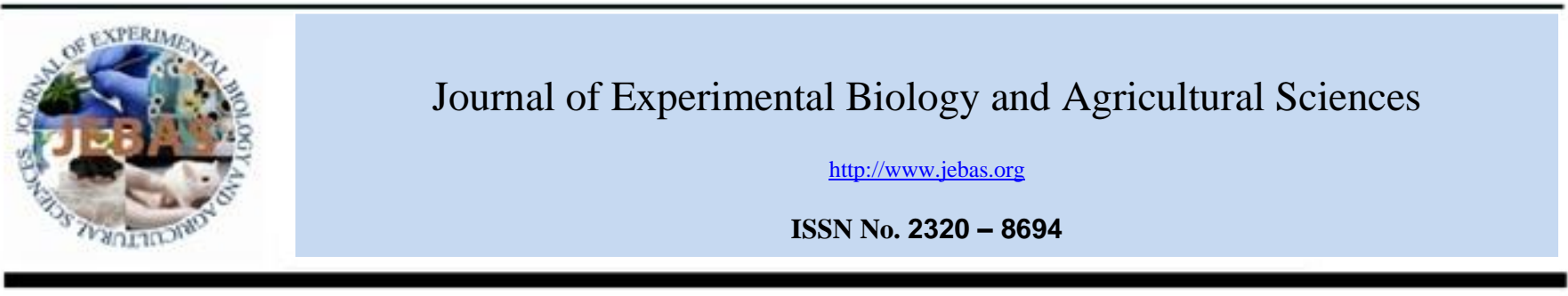

\title{
IMPACT OF ORGANIC FERTILIZATION ON MAIZE (Zea mays L.) PRODUCTION IN A FERRALITIC SOIL OF CENTRE - WEST CÔTE D'IVOIRE
}

\author{
Dogniméton Soro ${ }^{1,2, *}$, Koutoua Ayolie ${ }^{1,2}$, Ferdinand Gohi Bi Zro ${ }^{1,2}$, Ferdinand Yao Yéboua ${ }^{1}$, \\ Hippolitte Konan-Kan Kouadio ${ }^{3}$, Sidiky Bakayoko ${ }^{1,2}$, Pascal Téhua Angui ${ }^{4}$ and Justin Yatty \\ Kouadio $^{1,2}$
}

${ }^{1}$ Université Jean Lorougnon Guédé;

${ }^{2}$ UFR Agroforesterie ; Université Jean Lorougnon Guédé;

${ }^{3}$ UFR STRM, Université Félix Houphouët Boigny

${ }^{4}$ UFR Sciences et gestion de l'environnement, Université Nangui Abrogoua

Received - September 25, 2015; Revision - October 07, 2015; Accepted - December 14, 2015

Available Online - December 17, 2015

DOI: http://dx.doi.org/10.18006/2015.3(6).556.565

\begin{abstract}
KEYWORDS
Corn

Ferralitic soil

Organic fertilizer

Poultry manure

Yield

ABSTRACT

Importance of Corn's (Zea mays L.) crop is justified by its nutritious content especially because of the presence of high protein, minerals, vitamins and other energetic nutrients. In Côte d'Ivoire, maize production is insufficient and various strategies have been developed to improve its production. Present study was conducted in a ferralitic soil at the UJLoG's research station to evaluate the effect of two different ages (storage time) of chicken manure on growth and yield of GMRP-18 (an improved corn variety) and Bon-maïs (used for popcorn) varieties. Single dose of poultry manure at the rate of $7 \mathrm{t} / \mathrm{ha}$ was used in combination with $70 \mathrm{~kg} / \mathrm{ha}$. Various growth traits like germination rate, height, diameter, number of leaf, ear insertion level, number of ear per plant and yield have been evaluated. Results of study revealed positive impact of the manure on the growth and development of corn crops and highlighted the possibility of improving corn productivity in Daloa region by using poultry manure. Furthermore, higher plants growth was reported under the influence of fertilizer as compared to controls. Final yield is significantly enhanced by the contribution of manure and highest yield was reported on the six days wind stored poultry manure applied at the rate of $7 \mathrm{t}_{\mathrm{ha}}{ }^{-1}$.
\end{abstract}

\section{* Corresponding author}

E-mail: dognysoro@gmail.com (Dogniméton Soro)

Peer review under responsibility of Journal of Experimental Biology and Agricultural Sciences.

Production and Hosting by Horizon Publisher (http://publisher.jebas.org/index.html).

All rights reserved.
All the article published by Journal of Experimental Biology and Agricultural Sciences is licensed under a Creative Commons Attribution-NonCommercial 4.0 International License Based on a work at www.jebas.org.

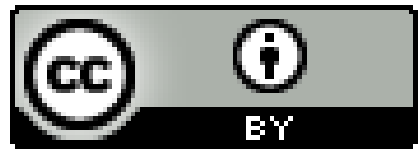




\section{Introduction}

Corn (Zea mays L.) is a widely consumed cereal crops throughout the world. It is used as a staple food for the peoples of the Northern region of Cote d'Ivoire and also contributes in animal feed. In Cote d'Ivoire it is consumed as a whole grains, couscous, or tôh which is the leg cooked corn flour. Fermentation of the corn grain is also carried out for the alcohol production and it serves as inter alia, for the preparation of beverages (the local beer, beer, whisky, etc.). Some companies produce infant's diets from corn and wheat foods. In animal feed, corn is a breeding crop which allows fattening cattle more quickly and thus increases the production of milk from cows (Yeo, 2011). An important part of corn production is intended for the feeding of poultry.

Despite all these benefits, Côte d'Ivoire produced very little amount of this crop which neither sufficient to satisfy the needs of its inhabitants nor the livestock. According to the Ministry of Agriculture report (2010) the estimated annual average production since 2000 to 2009 was 604 '031 tons on an average of 291' 852 hectares and it was approximately 2.3 tons per hectare (Yeo, 2011). Total annual corn production from country is still under exploitation and country fulfills much of its corn demand (63\%) by importing from Argentina (Anonymous, 2010). Higher production of this crop could help the country to get foreign currency by possible export and can offer farmers to get some additional incomes. Furthermore, excess production of corn can encourage the farmers to developed poultry farming.

Production of this crop is associated with several agroclimatic factors such as humidity, temperature, soil texture, soil fertility and soil erosion. Indeed, the decline in soil fertility and soil erosion reinforce pressure on land and justify low yields improvement in context of population growth and rapid urbanization (Agridea, 2007). All the necessary micro and macro nutrients required at higher amount for the higher production of this crop and deficiencies of these elements lead to decreases in growth. Application of chemical fertilizers help to overcome the nutrient deficiencies but excess use of these chemical fertilizers reduced the soil fertility by changing soil $\mathrm{pH}$. Corn is particularly tolerant with respect to the $\mathrm{pH}$ of soil and it can survive in a range of $\mathrm{pH} 5.2$ and 7.6, optimum corn production was reported between $\mathrm{pH} 6.5$ and 7 .

Chemical fertilizers needs could be substitute by introducing organic fertilizer, these organic fertilizers helps in increasing crop productivity without affecting soil fertility and $\mathrm{pH}$. Poultry manure contains a large mass of easily fermentable organic matter. It is a prime source of major nutrients such as nitrogen, phosphorus and potassium. Among various nutrients, nitrogen content is available dominantly, in the order of $20 \%$ on average (Itavi, 1997). This nitrogen is primarily available in the form of uric acid (61\%), organic nitrogen (31\%) and ammonia (8\%) (Rodhe \& Karlsson, 2002). Poultry manure also plays an important role in maintaining soil health by improving soil structure, root movement and retention of water which facilitating the plant growth. Dung has more alkalizing effect on the ground; their use will reduce the use of basic mineral amendments. The agricultural value of these manures varies with the time and storage time made changes in the concentration of mineral elements. Furthermore, this change in the nutritive values of these manures occurred due to phenomena of volatilization, leaching or reorganization. Phosphorus is very stable while potassium and nitrogen are very sensitive to changing environmental conditions. In addition, nitrogen and potassium are washable therefore rain water runoff causes reduction in the nutritive values of these manners.

Quality manure production is affected by various factors such as layout of livestock buildings, humidity, temperature, movements of animals, time of collection and losses of nitrogen in gaseous form. Fermentations also caused transformation of organic nitrogen into ammonium $\left(\mathrm{NH}^{4+}\right)$ later into changes in to ammonia gas $\left(\mathrm{NH}^{3+}\right)$ (ITAVI, 2013). Furthermore, losses occurred during storage are difficult to estimate, but in general it was reported between 10 and $20 \%$ (CORPEN, 2006). According to Kolawole (2014), period of fertilizer application also affect the crop production and the most critical period for fertilizer application is flowering approach (15-20 days before and after).

Farmers of Cote d'Ivoire are also careless in cleaning their chicken coop and storing manure. They did not have any knowledge regarding the quality changes carried out by wind and rain. The farmers used this collected manure without consideration of its age and its quality in order to fertilize the soils. By keeping above mentioned facts in mind, present study was carried out to determine the impact of poultry manure on the growth improvement and productivity of two corn varieties in centre west agroecological zon in Cote d'Ivoire.

\section{Materials and Methods}

\subsection{Study area}

Present study was conducted at the research station of the Jean Lorougnon Guédé University, Daloa, Côte d'Ivoire (figure 1). The experimental field was characterized by the dominancy of grasses with few woody species. Soils of the study area are mostly typics ferralitics onces with high organic matter. This ferralitic soils have good agricultural skills and are useful for the production of several agricultural products. Experimental area is sensitive to the soil erosion because of the continuous grass cover. There are two main seasons, in which rainy season start from the April and continue till October while the dry season occurred between November to March of every year. 


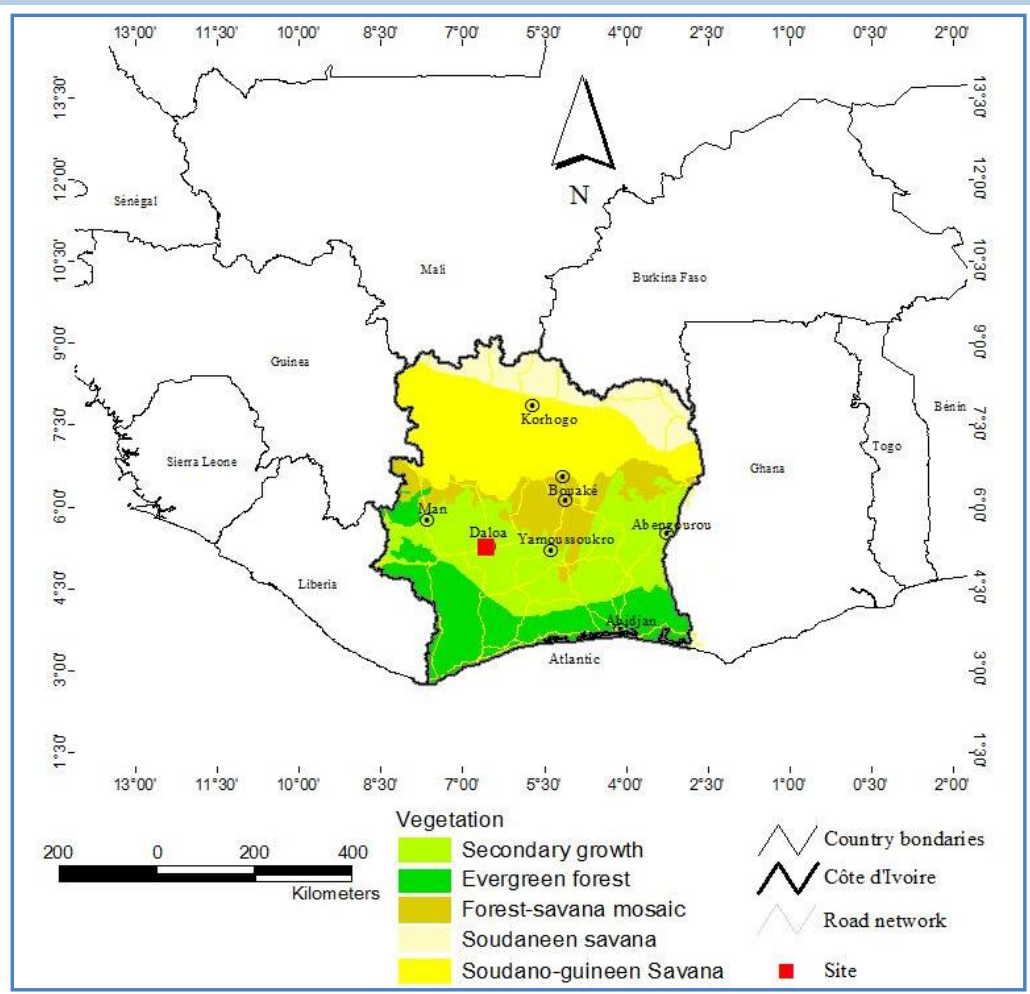

Figure 1 Presentation of the experimental site.

\subsection{Propagating material}

Two maize (Zea mays) varieties viz developed GMRP-18 (CNRA, 2006) and "Bon- maïs" were used in present study. GMRP-18 is characterized by high yield (approximately $5 \mathrm{t} / \mathrm{ha}$ ), yellow color, toothed, sweet taste, easy to grind, rich in essential amino acids, open pollination and a growing cycle of approximately 105 days. This variety is resistant to water lodging, rust or streak like diseases. Bon-maïs is trade variety with small yellow grains widely used for popcorn making.

\subsection{Fertilizers and fertilization}

Two different age's poultry manures viz 6 days and 6 months storage were used in this study. These manures were collected from the local farm located near the University, where these were stored under natural condition. Single dose (7t/ha) of both type of poultry manure were applied with $46 \%$ urea at the rate of $70 \mathrm{~kg} \cdot \mathrm{ha}^{-1}$. Poultry manure is used in bottom fertilizer with superficial tillage $(15-20 \mathrm{~cm})$ before sowing (the same day of sowing) while coverage fertilizer is provided in the form of urea dropped near the plantlet at the $45^{\text {th }} \mathrm{da}$ ).

\subsection{Experimental design}

Both varieties of corn seeds were sown in the month of May; this sowing was in line with two seeds per hill at approx 4-5 $\mathrm{cm}$ depth. Sowing is carried out at a distance of $0.80 \mathrm{~m} \times 0.30$ $\mathrm{m}$ or a density of 41.667 plantlets hills per hectare. The study was conducted by split-plot with two factors in 3 repetitions.
The corn variety being the main factor and the poultry manure the secondary factor. Weeding is an essential operation and it carried out two times during cropping cycle viz 28 and 45 days after showing (das).

\subsection{Parameters observed}

Various growth and development parameters such as rate of germination or lift, plant height, diameter, flowering date, ear insertion level, number of spikes per plant and yield per hectare was measured by standard methodology. Among these, germination rate was determined by the direct counting of number of seeds sown and number of seed germinated and it is represented by percentage. Plant height and diameter was directly measured by measuring tape while the date of flowing was calculated on the emergence of first and subsequent flower accordingly.

The crops were harvested after 105 days after sowing, the number of ear per plant was counted and the grains were weighed. These results formed the main data for the assessment of the action of the fertilizer on yield. Various parameters like number of heads, grain number per head, weight of 1000 grains and grains yield were determined to access the productivity but in present study weight of one thousand grains were not taken in consideration. The yield was calculated by the below mentioned formula: 


\section{Yield $(t / h a)=\frac{\text { Grains Weight }(t)}{\text { HarvestedArea }(h a)}$}

2.6 Statistic analysis

An analysis of variance (ANOVA) was made on data. The comparison of means was performed using the least significant difference (LSD) at the probability of 5\%.

\section{Results and Discussion}

\subsection{Soil and humidity}

The soil of study area has good texture and very few coarse elements were reported. The physical aspect of its fertility can be considered as satisfactory. The physical properties of studied soil revealed two main soil horizons i.e. surface and depth horizon at varying depth. Soil of the surface horizon was characterized by dark color, sandy-clayey texture, lumpy structure in aggregates rounded with abundance of fine roots to medium, horizontal and oblique, presence of earthworms and termites; few coarse elements. While the soil of depth horizon is in reddish color with clay texture, sub-angulaire polyhedral structure costs, very little vertical roots, low biological activity and absence of EG.

This study was carried out during the rainy season from May to August corresponding to the first cycle of corn production in the area. The number and regularity of rain have been recorded and revealed continuous 3 days, 5 days and 7 days rainfall with duration over an hour respectively in May, June and July. This phenomenon favors the development of high soil humidity.

\subsection{Germination rate}

The rate of germination was first time calculated after three days of showing and it is continued up to the 12 days. Results of germination rate study suggested that both the studied verities have good germination rate and it was reported 86.6 and $92.0 \%$ for Bon-maïs and GRMP-18 varieties respectively. No significant difference was reported between the different age's fertilizer application and control but two corn varieties significantly differ to each other in germination. This germination occurs regardless of the fertilization type.
3.3 Growth and development characteristics of plants

\subsubsection{Plant growth}

Both varieties had similar growth pattern and can be represented by sigmoid growth curve, both the varieties reached to the different height but among these two the rate of growth is higher for the GMRP-18 variety compared to Bonmaïs and it gain maximum height. For each variety, fertilization level influences the pace of growth. Plants fertilized by six days stored manure had higher plant height as compared to plants fertilized by six months storage manure for both corn varieties (Figure $2 \& 3$ ).

\subsubsection{Plant vigor (diameter)}

Estimation of radial plant growth was carried out on regular basis between the $17^{\text {th }}$ to $45^{\text {th }}$ das. Beyond the $31^{\text {st }}$ das, the large diameter regressed and reached the $38^{\text {th }}$ values smaller than the $31^{\text {st }}$ stocked. Furthermore, the final diameter is identical for the two ages of droppings for the GMRP-18 variety. Male flowering occurred from the $45^{\text {th }}$ das and heading starts from the $50^{\text {th }}$ das. Like plant growth, for plant vigor also six days stored fertilizer application shows superiority over the six months storage fertilization. A significant difference was reported between these two and this difference is more pronounced for the GMRP-18 than the pop corn variety (Figure $3 \& 4$ ).

\subsubsection{Ear insertion}

The ear level is an important factor which can be taken into account with the potassium content in maize and lodging resistance. For both varieties, ear inserts at an average height of between $1 / 3$ and $1 / 2$ of height from the foot of corn (Figure 5). A positive correlation was reported between the ear insertion level and plant hight and for both varieties highest ear insertion and plant height was reported at the six days stored fertilizer application. For GMRP-18, six days stored fertilizers application shows highest plant hight which reached upto the $250 \mathrm{~cm}$ while it was reported only $205 \mathrm{~cm}$ for the 6 month storage fertilizer application for the same variety. The trends are similar for the ear insertion level also. As compare to GMRP-18, Bon maïs varitey is showing poor performance but it is showing superiority over the control and a significant difference was reported among these two varieties.

Table 1 Effect of fertilizer application on the germination of corn seeds.

\begin{tabular}{|lcccccc|}
\hline Manure & \multicolumn{2}{c}{ 6 Days Storage } & \multicolumn{2}{c|}{ 6 Months Storage } & \multicolumn{2}{c|}{ No Manure (Control) } \\
\hline Variety & GRMP-18 & Bon-maïs & GRMP-18 & Bon-maïs & GRMP-18 & Bon-maïs \\
\hline Germination rate (\%) & 92 & 86.67 & 90.67 & 85 & 92 & 74.67 \\
\hline
\end{tabular}




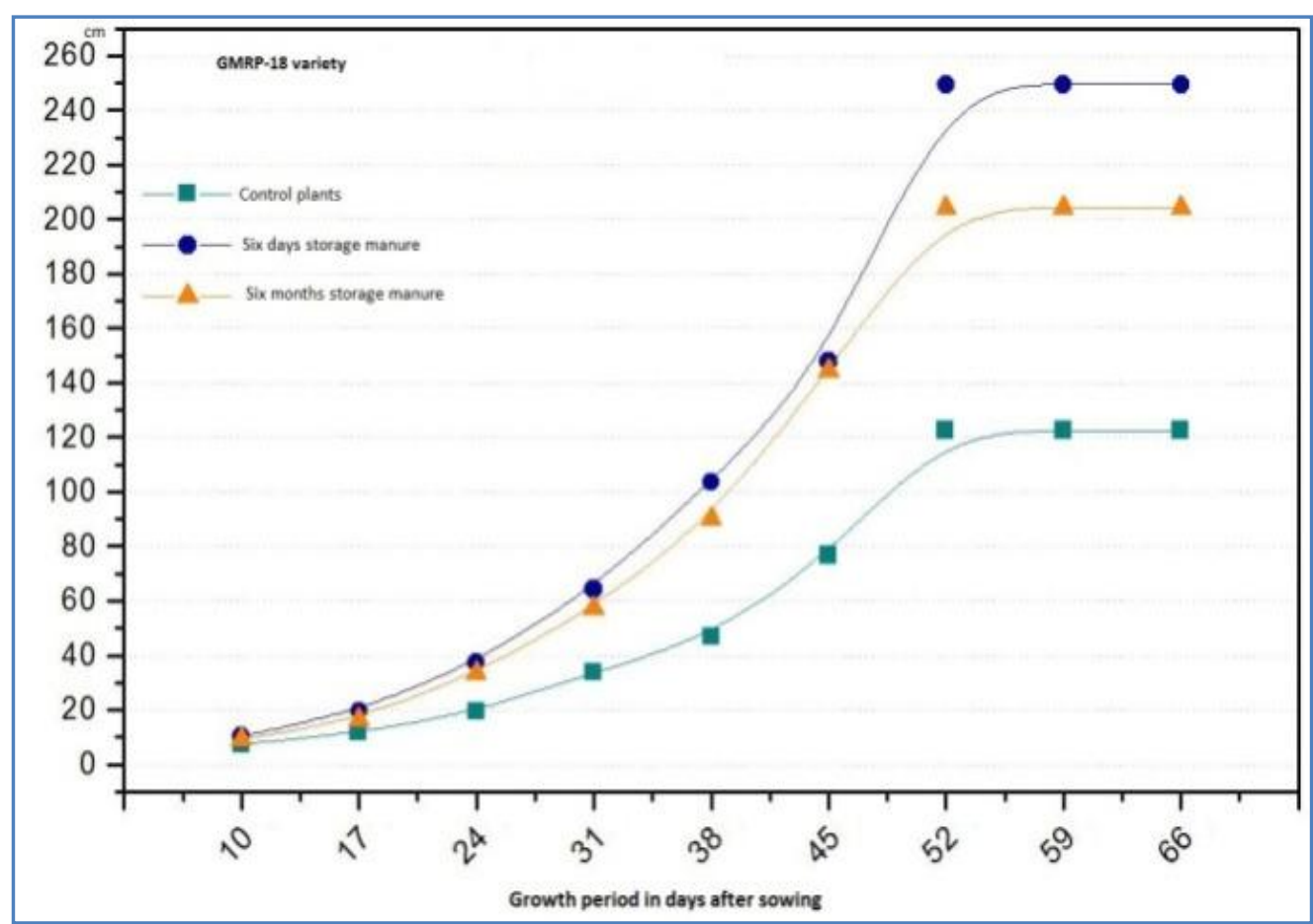

[2a. GMRP-18 (Data presented in figure are mean of three replicates)]

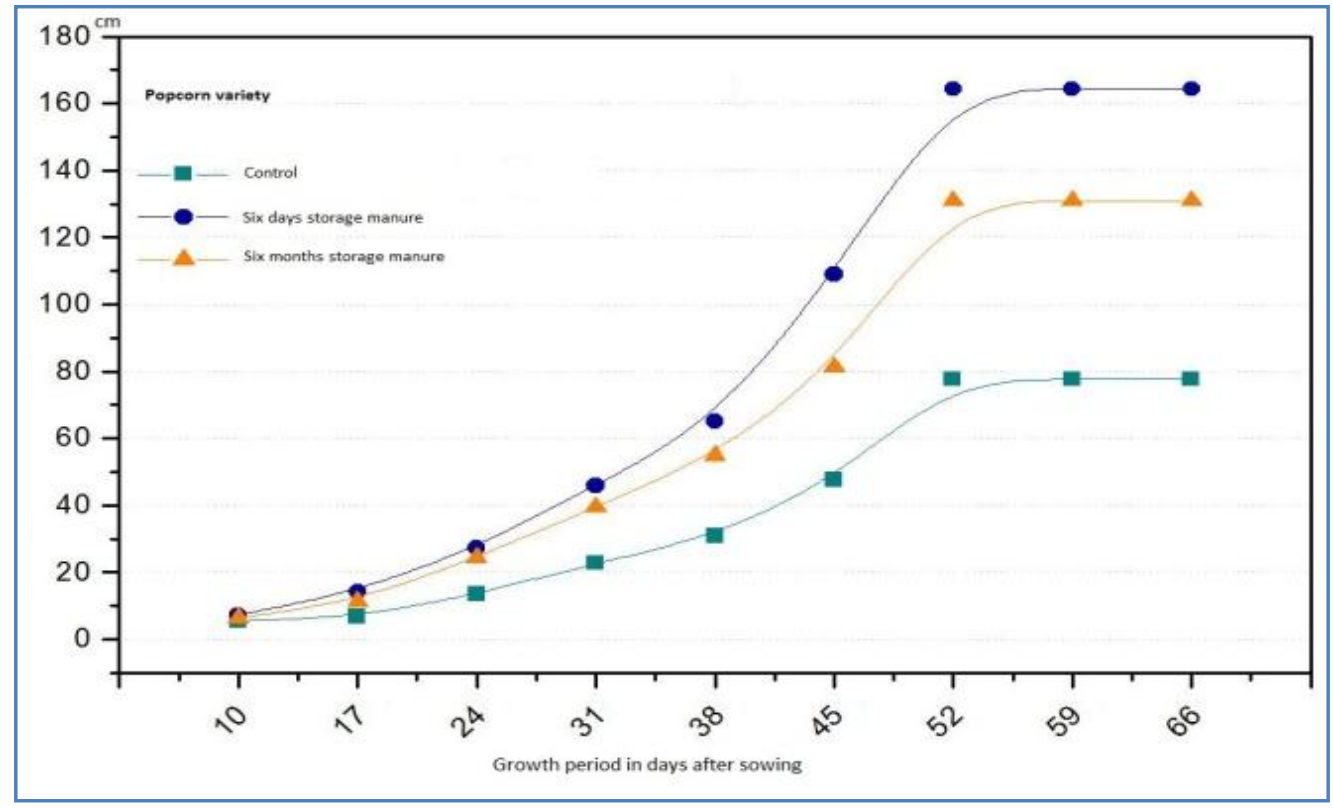

[2b. Bon-maïs (Data presented in figure are mean of three replicates)]

Figure $2(\mathrm{a} \& \mathrm{~b})$ Represent plants growth evolution curves under the influence of poultry manure. 


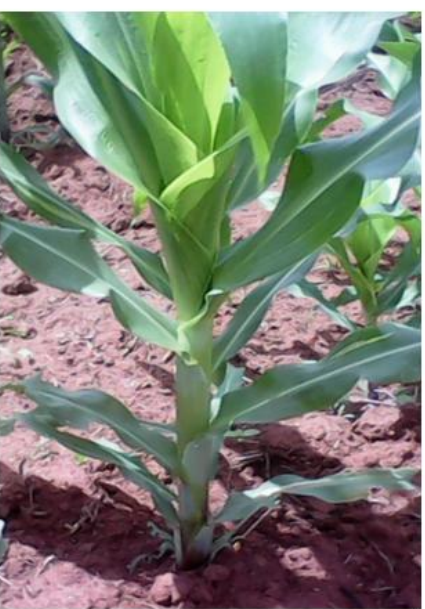

a.GRMP-18 plant aspect with the six days storage manure (Echelle :1200x1600)

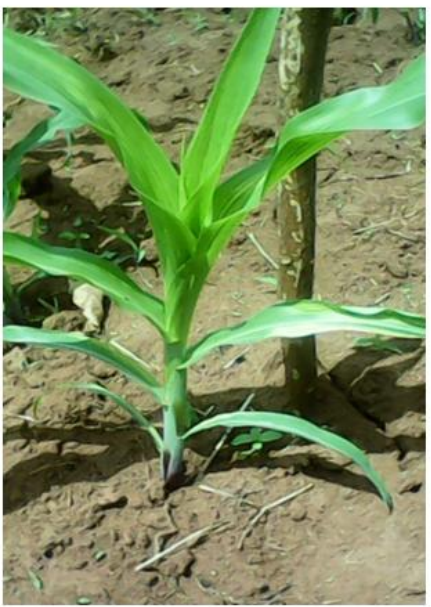

b.Pop-corn plant aspect with the six months storage manure (Echelle :1200x1600)

Figure 3 Maize plantlet at 30 days after sowing.

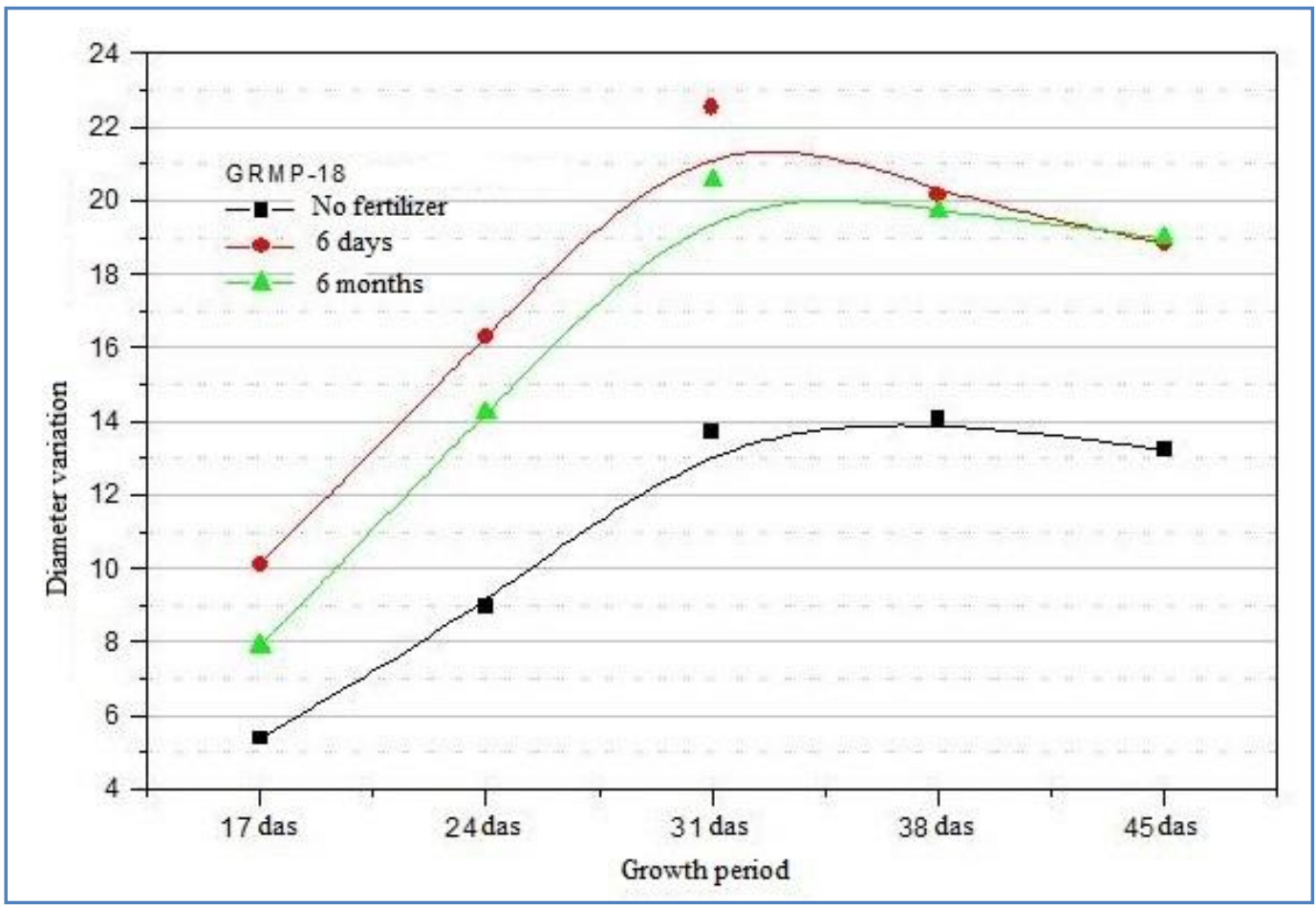

4a. GMRP-18 (Data presented in figure are mean of three replicates). 


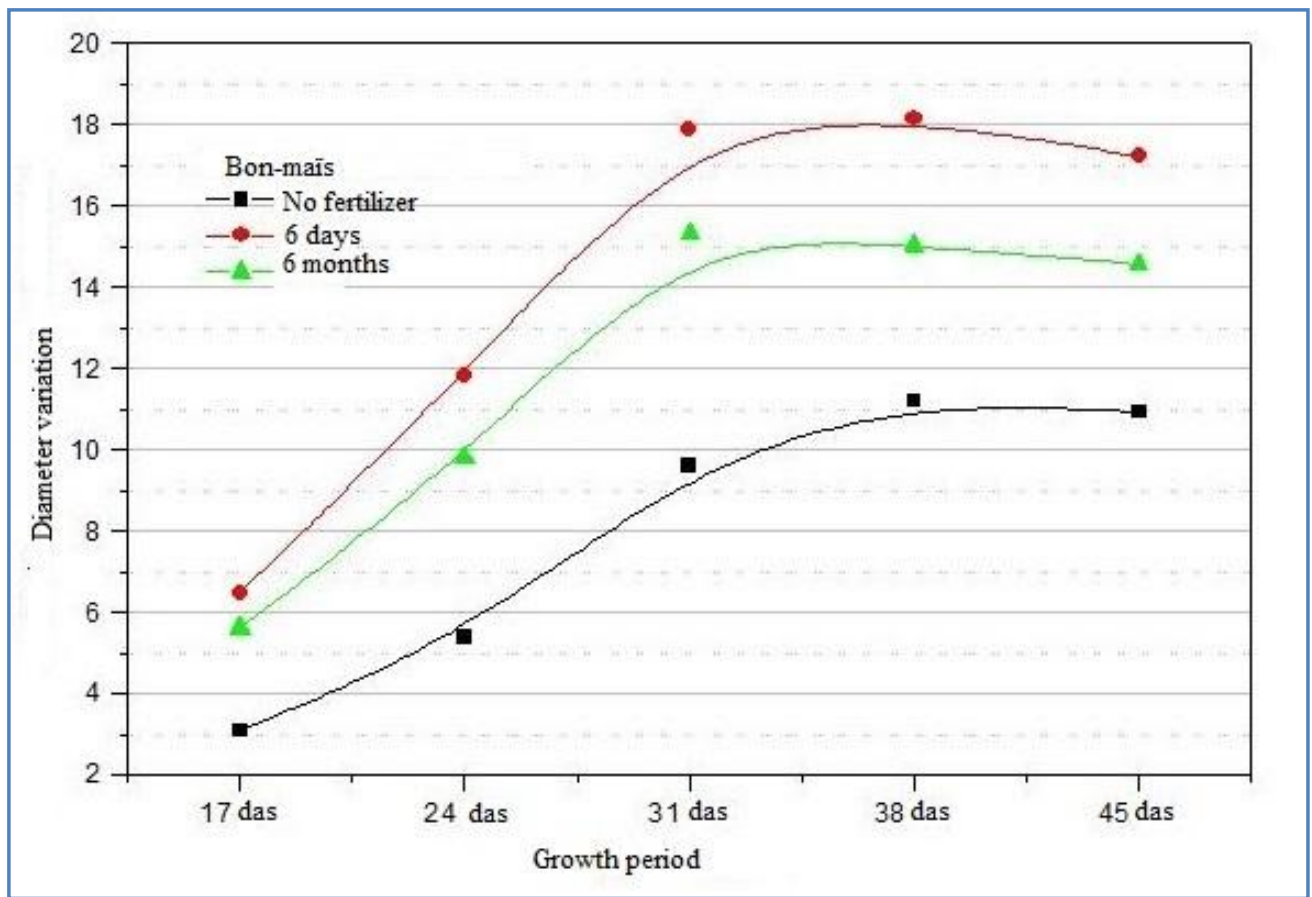

$4 \mathrm{~b}$ Bon-mais (Data presented in figure are mean of three replicates)

Figure 4 (a \& b) Represented vines diameter curves under the influence of fertilizer

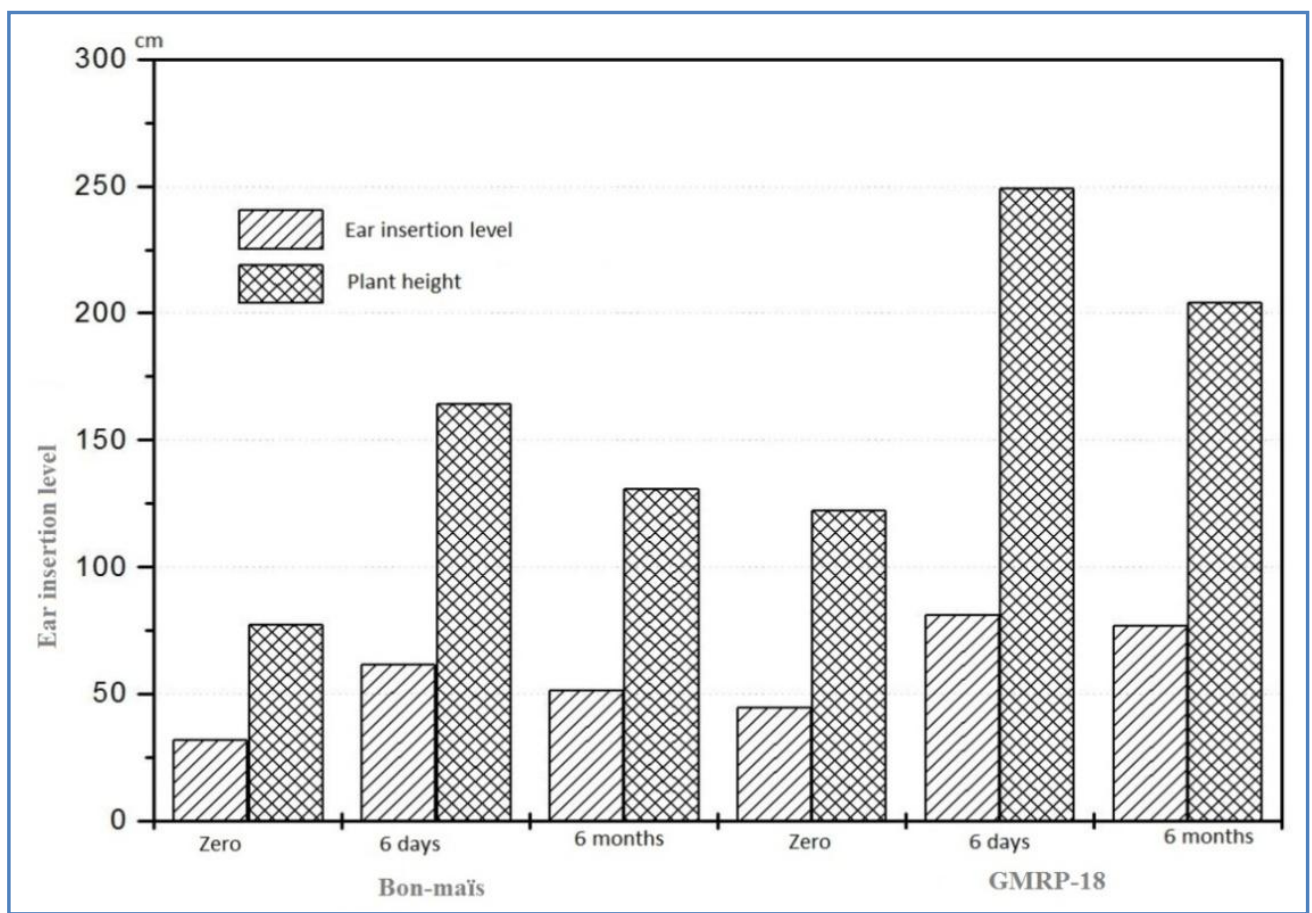

Figure 5 Spike insertion level and plant height (Data presented in figure are mean of three replicates). 
3.4 Corn Yield

Although bon-maïs variety has higher number of spikes (1.2) per plant it was showing poor performance than the GMRP-18 variety which has less spike/plant (1 spike/plant). The yield difference is highly significant between these two varieties (P
$=0.000149, \alpha=0.05)$ and depending on the level of fertility. Registered yields are of the order from 2.72 to 4.81 t/ha (6 days-droppings) for GMRP-18 and 0.58 to 2.31 t/ha (6 daysdroppings) for Bon-maïs variety. They are dubbed for GMRP18 in six days of conservation of the droppings from the witness and four times greater than bon-maïs variety.

Table 2 Model strength.

\begin{tabular}{|lcccccc|}
\hline Source & DDL & $\sum$ of scare & Mean scare & F & Pr $>$ F & \\
Model & 10 & 57.912 & 5.791 & 9.843 & 0.000149 \\
\hline Error & 13 & 7.649 & 0.588 & & & \\
\hline Total corrected & 23 & 65.561 & & & \\
\hline
\end{tabular}

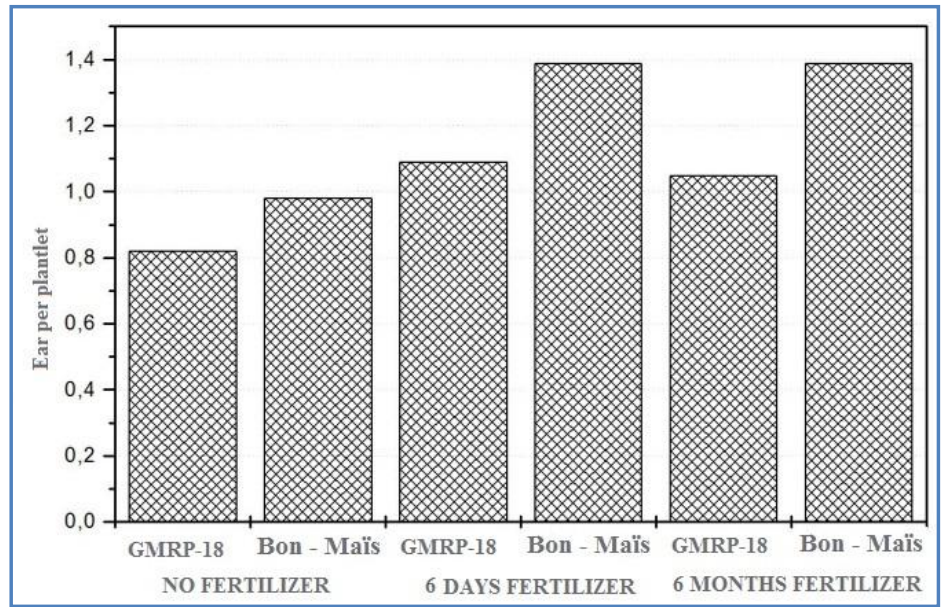

6.a. Number of spike per plantlet (Data presented in figure are mean of three replicates)

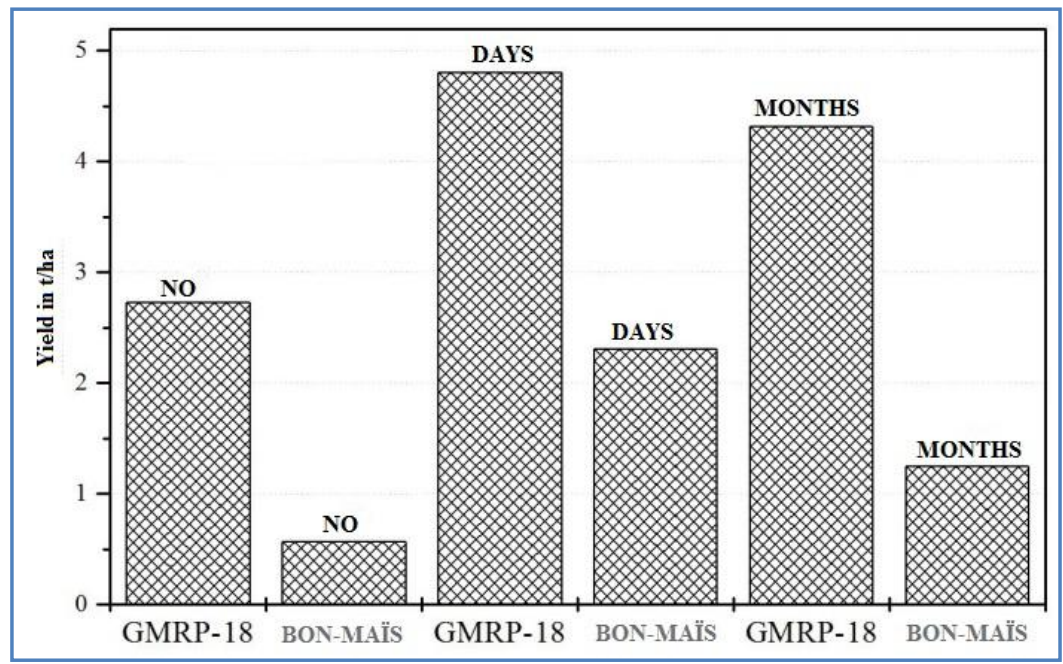

6.b Corn yield in $\mathrm{t} / \mathrm{ha}$ (Data presented in figure are mean of three replicates)

Figure $5(\mathrm{a} \& \mathrm{~b})$ Production of corn $(\mathrm{No}=$ without fertilizer, DAYS $=$ fertilizer 6 days of storage and MONTHS = fertilizer 6 month storage) 
Poultry manure has been widely used as organic fertilizer and it has significant effect on the soil fertility by adding both major and essential nutrients as well as soil organic matter which improve moisture and nutrient retention. In present study higher soil humidity was reported in the plot treated by manure. This high humidity favor the germination of corn seeds and it was reported that the seeds sown in fertilized field germinate only three days after sowing with a final average of $86.6 \%$ and $92 \%$ for Bon mais and GMRP-18 varieties respectively which is higher than the control. This germination is made regardless of the fertilization level and reflects the fact that both varieties seed kept their germination power. Furthermore, grains of bon-maïs had an excellent level of germination $(>75 \%)$ and could be used in the production of this type of corn as seed (Soro et al., 2014).

In present study, all tested parameters revealed a positive correlation between the manure level and plant growth. Similar type of findings was reported by various researcher (Maman \& Mason, 2013; Namazi et al., 2015; Okoli \& Nweke, 2015). Age of manure affected the plant growth and plants fertilized with the manure of six days storage had a greater growth rate than plants fertilized with the six months storage manure. Manure fertilized plot showed superiority over the control and grew faster. These growth rates indicate the availability of different nutrients at various levels in poultry manure. Similar type of results was reported by Ziadi et al., (2006) and Dikinya \& Mufwanzala (2010) and suggested that application of poultry manure increased soil fertility and crop production. Nitrogen and phosphorus are the important nutrients which play major role in the cell growth. The growth of maize could be justified by a higher dose of nitrogen and phosphorus in manure for six days storage compared to that of six months storage. Results of present study are in accordance with the findings of Dulac (1955), who have reported variation in the mineral elements of corn plants and it varies according to the age of the poultry manure. Furthermore, Kaiser (2006) reported the higher concentration of phosphorus in manure and it has stimulatory effect of the corn plant growth. This difference can be confirmed by the lowest nitrogen content in the manure stored for 6 months as compared to that of 6 days storage. These results are confirmed by the finding of Tremblay (2006) confirming that corn (Zea mays L.) grain yield is significantly influenced by nitrogen supply.

The assessment of the number of spikes and grain yield helped to understand that grain yield is not bound with the number of ears per plant. A better assessment of the growth potential can be given by the weight of thousand grains. Kaiser (2006) suggested that the poultry manure is a good source of phosphorus and help in the seed set in corn crop and has higher weight of 1000 seeds. Similarly Kolawole (2014) also reported that the fertilizer application period has significant effect on the corn production. According to Kolawole (2014) two week prior application of poultry manure increases the corn production and level of phosphorus in the soil. The rootcollar diameter reduction could make corn verse sensitive if the weight of the spur is large and high enough. The level of insertion (bottom) seems to strengthen the soundness of the plant and strengthen resistance to lodging. Indeed, no plant has fallen under the influence of wind throughout the cycle. The variation in diameter can be explained by a remobilization of nutrients toward the reserves organs, but also to a decline in the rate of these elements in the soil and confirm the strong dependence of corn to nitrogen $(\mathrm{N})$ and potassium (Khaliq et al., 2004). Loss of potassium is less when stored in the same conditions otherwise, this element has a lesser importance in the diet of maize compared to nitrogen. The difference in the growth of two varieties may result in a genetic variation but it is more pronounced because of the difference in nutrients availability. Manure lost its nutrient with the storing period; by runoff, evaporation or leaching, this lost was usually estimated between 10 to 20\% (Corpen 2006). Considering the mode of fertilizer storage, it can be conclude that the improper storage of manure causes more loses in nutrients (Equiterre, 2009). Among various available nutrients, nitrogen and potassium are susceptible to the changing climatic conditions (temperature, wind rain) and degrade or lose rapidly. Therefore the difference in growth of present study can be justified by the loss of nitrogen and other mineral contents under storage conditions. However, the meaning of this variation seems to be reversed to reflect to the maturing of the manure during storage.

\section{Conclusion}

Result of study revealed that poultry manure help in improving plant growth characteristic and final production. The improved performance is also statistically similar to that achieved with mineral fertilization. It is a good initiative for the improvement of the production of corn in Côte d'Ivoire. Furthermore, it was reported that storing time has negative impact on the quality of manure and a significant reduction was reported. Therefore it is recommended to the farmers that they should stored manure under less temperature fluctuation conditions and away from the rain. This study could be popularized with producers in order to demonstrate the potential of the poultry manure.

\section{Acknowledge}

The authors thank Jean Lorougnon Guédé University responsible for permitting this experience and Mr Koffi, chicken breeder in Daloa for providing us poultry manure of different ages.

\section{Conflict of interest}

Authors would hereby like to declare that there is no conflict of interests that could possibly arise.

\section{References}

Agridea (2007) Maïsculture 4.5.72.bio. Fiche technique. Pp 7 available on http://www.bioactualites.ch/fileadmin/documents/bafr/producti 
on-vegetale/grandes-cultures/4.5.11-73_Mais.pdf access on 15th August, 2015.

Anonymous (2010) Programme de renforcement et de recherche de la sécurité alimentaire en Afrique de l'ouest Pp 10.

CNRA (2006) Bien cultiver le maïs en Côte D'Ivoire ; Fiche technique Pp. 4.

Corpen (2006) Estimation des rejets d'azote, phosphore, potassium, calcium, cuivre et zinc par les élevages avicoles Pp. 7 available on http://www.developpementdurable.gouv.fr/IMG/pdf/DGALN_2007_10_rejet_elevage_avi cole.pdf access on 15th August, 2015.

Dikinya O, Mufwanzala N (2010) Chicken manure-enhanced soil fertility and productivity: Effects of application rates. Journal of Soil Science and Environmental Management 1: 4654.

Dulac J (1955) Diagnostic foliaire des céréales. III. Application de la relation azote-rendement au Maïs. IV. Relation entre la teneur en azote de la feuille de l'épi, le rendement à l'hectare, le rendement par pied et la densité chez le Maïs. Comptes-rendus des Séances de l'Académie d'Agriculture de France 500-507.

Equiterre (2009) Les amendements organiques : fumiers et composts Pp5 available on http://www.agrireseau.qc.ca/agriculturebiologique/documents/ MARAI_Chapitre_12Amendements.pdf access on 15th August, 2015.

ITAVI (1997) L’ammoniac, sciences et techniques avicoles, hors série septembre $1997 \quad$ 49-52p www.itavi.asso.fr/elevage/batiment/ Edition ITAVICNEVA.28-rue du rocher-75008 paris. (Consulté 17 décembre 2014)

ITAVI (2013) Estimation des rejets d'azote-phosphorepotassium-calcium-cuivre et zinc par les élevages avicoles Pp 63.

Kaiser DE (2006) Use of poultry manure as a phosphorus source for corn production in Iowa. Retrospective Theses and Dissertations Paper 1884 submitted to the Iowa State University available on http://lib.dr.iastate.edu/cgi/viewcontent.cgi?article=2883\&cont ext=rtd access on 15th August, 2015.
Khaliq T, Mahmood T, Kamal J, Masood A (2004) Effectiveness of Farmyard Manure, Poultry Manure and Nitrogen for Corn (Zea mays L.) Productivity. International Journal of Agriculture \& Biology 6:260-263.

Kolawole GO (2014) Effect of time of Poultry manure application on the performance of Maize in Ogbomoso, Oyo State, Nigeria. Journal of Applied Agricultural Research 6: 253-258.

Maman N, Mason S (2013) Poultry manure and inorganic fertilizer to improve pearl millet yield in Niger. African Journal of Plant Science 7: 162-169. DOI: 10.5897/AJPS12.010.

Namazi E, Lack S, Nejad EF (2015) Effect of vermicompost and chemical nitrogen fertilizer application on the various functioning of maize seeds. Journal of Experimental Biology and Agricultural Sciences 3: 261-268. doi: http://dx.doi.org/10.18006/2015.3(3).261.268.

Okoli PSO, Nweke IA (2015) Effect of poultry manure and mineral fertilizer on the growth performance and quality of cucumber fruits. Journal of Experimental Biology and Agricultural Sciences 3: 362-367. doi: http://dx.doi.org/10.18006/2015.3(4).362.367.

Rodhe L, Karlsson S (2002) Ammonia Emissions from broiler Manure- influence of storage and spreading Method. Biosystems Enginering 82:445-462.

Soro D, Ayolié K, Bakayoko S, Dao D, Yatty K.J, Gnakri D. (2014) Can Kponan yam (Dioscorea cayenensis) full season tuber sprout if planted? Journal of Agricultural Science and Technology, Volume 4, Number 4B, 2014 : 312-320.

Tremblay G (2006) Les besoins en azote du maïs-grain. Journée d'échange sur l'azote. CRAAQ.

Yéo YA (2011) Analyse de la compétivité du mais locale en Cote d'Ivoire, Elève ingénieur Agroéconomiste de la 4le promotion ENSA Boubacar Diallo, MSU. Pp.10.

Ziadi N, Gagnon B, Cambouris A (2006) Utilisation des engrais minéraux azotés en grandes cultures : Description des différentes formes et leurs impacts en agroenvironnement. Pp. 29 available on http://www.agrireseau.qc.ca/agroenvironnement/documents/Zi adi_N_resume_PPT.pdf accessed on 21 September 2015. 